\title{
Article \\ Monitoring Consumer Purchasing Behavior for Wood Furniture before and during the COVID-19 Pandemic
}

\author{
Andreja Pirc Barčić ${ }^{1, *}$, Manja Kitek Kuzman ${ }^{2}$, Tihana $\operatorname{Vergot}^{1}$ and Petra Grošelj ${ }^{3, *(1)}$ \\ 1 Department for Production Management, Faculty of Forestry and Wood Technology, University of Zagreb, \\ Svetošimunska 23, HR-10000 Zagreb, Croatia; tihana.vergot@gmail.com \\ 2 Department of Wood Science and Technology, Biotechnical Faculty, University of Ljubljana, Jamnikarjeva 101, \\ SI-1000 Ljubljana, Slovenia; manja.kuzman@bf.uni-lj.si \\ 3 Department of Forestry and Renewable Forest Resources, Biotechnical Faculty, University of Ljubljana, \\ Jamnikarjeva 101, SI-1000 Ljubljana, Slovenia \\ * Correspondence: apirc@sumfak.unizg.hr (A.P.B.); petra.groselj@bf.uni-lj.si (P.G.); \\ Tel.: +385-1-235-25-67 (A.P.B.)
}

Citation: Pirc Barčić, A.; Kitek Kuzman, M.; Vergot, T.; Grošelj, P. Monitoring Consumer Purchasing Behavior for Wood Furniture before and during the COVID-19 Pandemic. Forests 2021, 12, 873. https: / / doi.org/10.3390/f12070873

Academic Editors: Masaji Sakagami, Daishi Sakaguchi and Mark Hughes

Received: 28 May 2021

Accepted: 23 June 2021

Published: 1 July 2021

Publisher's Note: MDPI stays neutral with regard to jurisdictional claims in published maps and institutional affiliations.

Copyright: (C) 2021 by the authors. Licensee MDPI, Basel, Switzerland. This article is an open access article distributed under the terms and conditions of the Creative Commons Attribution (CC BY) license (https:/ / creativecommons.org/licenses/by/ $4.0 /)$.

\begin{abstract}
Monitoring consumer buying behaviors in terms of their preferences and attitudes has been known as an important driver for the success and development of various industries, including a wood furniture manufacturing. The aim of this study was to identify and compare the purchasing behaviors of furniture consumers in the period before and during the COVID-19 pandemic. Two surveys were conducted in Croatia, the first in April and May 2020 with the assumption that consumer purchasing behaviors will change during the COVID-19 pandemic in the following year and the second one during March 2021. Differences regarding consumer purchasing behaviors and preferences for wood furniture between respondents regarding demographic and economic factors before and during the pandemic were found. The coronavirus pandemic is teaching us all hard lessons about resilience and adaptability, and new opportunities and solutions are essential. Nowadays, it is becoming increasingly important to produce information. Research offers insights into future design and building communication to better meet the information needs of different types of consumers and to more broadly increase the acceptance and appeal of wood furniture in society in the spirit of sustainable and bio-based circular economy.
\end{abstract}

Keywords: wood products; furniture; preferences; consumer behavior; purchasing; COVID-19 pandemic; Croatia

\section{Introduction}

In a market environment that is constantly changing, understanding customer buying behavior is crucial for companies to operate successfully and efficiently. Understanding consumer behavior is considered the cornerstone for successful marketing, reliable production management, and the success of research and development activities [1]. It is about understanding how individuals, groups, and organizations select, purchase, use and dispose of products, services, ideas, and experiences to satisfy their wants and needs. The most important goal of marketing is to satisfy the desires and needs of the target group of consumers [2]. To be successful, marketing experts need to know consumers' desires, thoughts, and attitudes and how to satisfy those needs, which is not an easy task, because consumers tend to make reckless purchasing decisions [3-6].

Every person experiences the world differently, and reality for the individual is only what he perceives as existing. However, this experience is also based on personal needs, desires, values, and experiences. Many consumers see their homes and furniture as an extension of themselves. In this respect, the purchasing of furniture can be seen as an emotional purchase [7-9]. On the other hand, Høibø et al. [10] showed that there are other factors that have a stronger influence on the material preferences of respondents in urban 
buildings than if they come from a country where wood is an uncommon building material or from a country where wood is widely used.

In addition, even if furniture is not functionally necessary, it is now a status symbol and is usually considered a durable investment. Preferences are typical in the consumer market, and according to Dhar [11], consumers are often faced with situations where they have to choose between several alternatives.

A commonly used model to explain the consumer decision-making process was developed by Engel, Kollatt and Blackwell (EKB model) in 1968. The model consists of a five-step path (problem/need identification, information search, evaluation of alternatives, purchase decision, and post-purchase behavior) that consumers must go through when deciding which product they will buy [3,12]. In this process, they examine and evaluate the functional benefits of the product, using a range of criteria to evaluate alternatives and often spending a great deal of time before making a final decision. This is particularly true for higher-value products such as furniture, where customers choose very carefully between different alternatives [3].

However, the world has changed and so has the way consumers search for information today. Nowadays, consumers have almost unlimited access to various information, are exposed to numerous product advertising activities [13], and new retail concepts have created more options for consumers to choose from [14]. In addition, consumers today often know the price range, style, and features of the product in question before even entering the retail store [15]; share their personal experiences with the brand through reviews, recommendations, and product descriptions; and find ideas through search engines and social media services [16]. Consumers can be classified into similar groups with homogenous needs market segmentation [17], which may differ in terms of age, gender, education, profession, geographic location, purchasing power, buying behavior and practice, interest, wants, and needs of consumers [2,18]. Nicholls and Stiefel [19] found that sociodemographic factors such as age, gender, and income were associated with preferences for a variety of wood products. Compared to paid advertising and/or company representatives, informal communications with consumers are considered credible sources in the decision-making process for specific products [18], and in addition, social media can be used to integrate consistent views from consumers in the decision-making process [20]. According to Ponder [8], manufacturers and retailers should keep in mind that they are not only making or selling a product but also providing a way for consumers to conveniently spend time with family and friends. A number of studies on the impact of purchasing decision related to furniture $[17,21-23]$ show the importance for furniture companies to gain a better understanding of such decisions, as this can help them to create a combination of products and services that satisfy consumers' needs and desires. A better understanding of purchasing decisions in the consumer market would enable furniture companies to influence consumers at each stage of the decision-making process. In addition, the knowledge of customer needs and requirements could help improve the production and business results of companies in the wood industry [24].

Customer buying habits and demands are constantly changing. Thus, consumers pay more attention to the money they spend, the products they buy, and the risks they take when choosing products [1]. When making a purchase decision, consumers have various channels through which they can research and learn about the range of desired products in the market. According to Alok [25], the factors that influence the choice of channels for product information research are: the risk that the channel provides information, the intention to search and compare prices, the effort to search and evaluate, and the delivery time of the product. Smart purchasing is a term that refers to the combination of these channels when making a purchase decision, and the ability to make a purchase decision in this way makes the consumer more satisfied and provides a strong bond between the seller and the consumer [26]. When the consumer decides to research the information about the product on the seller's website and finally makes a purchase in the store, it is webrooming. In contrast, showrooming is when the consumer physically examines the 
product in the store and makes the purchase online [27]. How the consumer researches the product before making the purchase decision depends on how much effort and time they are willing to invest in this process. Due to saving effort and time, consumers are more likely to opt for webrooming [26]. Voramontri and Klieb [28] found that, in addition to the websites of sellers and manufacturers, customers also get information about products through social networks. This is especially true for younger customers who spend more time online [27]. On the other hand, consumers are more confident that they have made the right decision when they use showrooming channel combinations [26]. In addition, online shopping often offers benefits such as free shipping or a discount (e.g., if the consumer subscribes to the newsletter). On site channels, combinations are also possible, meaning that consumers browse for products in stores while exploring alternative options and prices online from other sellers [29]. Further, manufacturers and retailers should keep in mind that they are not only making or selling a product but also providing consumers with a way to conveniently spend time with family and friends [8].

According to Waswo [30], furniture is an important part of an apartment, and it takes about $35-45 \%$ of the floor space. The study conducted by Husein [31] investigating the impacts of multifunctional furniture on the space efficiency of small apartments to improve human well-being in Erbil City showed that, with the help of multipurpose furniture, it is possible to meet the various needs of residents in a limited space. Additionally, the study noted that a bed, a wardrobe, and table were the most preferable pieces of furniture to have in an apartment. Aras and Özdemir [32] noted that rural vs. urban life affected furniture preferences. More precisely, respondents coming from rural areas preferred traditional furniture, while respondents from big city centers preferred modern and innovative furniture styles.

Wooden furniture has a significant market share in the global furniture market due to its natural appearance, durability, ease of use, resilience, and ecofriendly properties [33,34]. The COVID-19 outbreak has directly impacted the forest product market and indirectly through the market for finished wood products [35]. For example, in April 2020, United States (US) imports of furniture and home furnishings were down $\$ 1.2$ billion in comparison to the same period in 2019 [36], and according to Jackson et al. [37], this phenomenon was not limited to the U.S. According to the United Nations and the Food and Agriculture Organization of the United Nations [38] Annual Market Review-2019 to 2020, office furniture accounts for about $10 \%$ of the total furniture consumption in Europe. Additionally, the value of the market grew for several years to reach $\$ 10$ billion in 2019, noting that Germany, the United Kingdom (UK), and the Netherlands were the largest single consumers. The market for Chinese-made office furniture is increasing and accounts for $9 \%$ of European consumptions.

Nevertheless, the consequences of the COVID-19 pandemic on office furniture consumption vary among countries. Overall, furniture trade is dependent on the global supply chain. In 2020, the EU wooden bedroom furniture market decreased for the first time since 2017 [39]. However, Hayes et al. [40] stated that, with COVID-related shutdowns and stay-at-home times, many people found the time for home improvement projects, which created additional demand for wood products.

According to Shoji et al. [41], the furniture industry is one of the markets that are most influenced by consumer behavior. Therefore, it is necessary to study the needs and desires of potential consumers and, at the same time, to study the prepurchase factors that influence consumers in the process of purchase decisions. In Southeastern Europe, problems occurred during the transition period from a planned economy to a market economy, mainly related to the privatization of enterprises and entry into highly competitive global markets [42,43]. In the last 10 years, Croatia has made many economic and social changes that either directly or indirectly affected the furniture industry. There have been many important changes in the field of furniture products and sales in Croatia related to the development and application of marketing functions. These changes, along with factors such as geographic location, infrastructure development, skilled labor, input prices, and government efforts to 
attract foreign investments, have made these markets more interesting both to domestic and foreign investors. For Croatia, membership in the European Union (EU) is important. Croatia joined the EU in 2013. In terms of size and population, Croatia has an area of approximately $57,000 \mathrm{~km}^{2}$ and a population of approximately 4.2 million [44]. In 2019, in terms of standard of living, for example, the average monthly net salary in Croatia was approximately 860 euros (EUR), and the gross domestic product (GDP) growth rate was $2.9 \%$ [45].

The share of furniture consumption in Croatia in the total EU furniture consumption was $0.4 \%$ [46]. Additionally, the furniture consumption per capita in Croatia reached about 81 EUR in 2012. In 2017, the share of the sales value of furniture in the total sales value was $2.5 \%$ [47].

If we consider the construction activity of legal entities employing five or more persons, the value of executed works on residential buildings amounted to approximately 300 million, and in 2016, 7800 apartments for permanent residence were completed in Croatia [47]. The demand for wood products is a derived demand in terms of how it is created, e.g., the furniture demand is mainly derived from the demand for residential and civil buildings.

In order to develop and implement a successful marketing strategy, a comprehensive understanding of consumer furniture preferences in the buying process is necessary. A common assumption is that a consumer identifies a problem, searches for information, and evaluates alternatives before making a purchase decision $[48,49]$. Together, these events can also be referred to as the prepurchase stage of the customer journey [50]. In addition, understanding the purchasing behavior of furniture consumers would provide information that is useful to the furniture industry. Studying certain demographic categories of customers in terms of their preferences provides a better understanding of consumer behavior. The pandemic affected virtually every aspect of our lives. The way we used to live has been completely changed due to the COVID-19 pandemic and has had a profound impact on consumer buying patterns. Furniture purchases are taking place online. To get an insight into the changes in consumer behaviors and their buying habits, the observation of their buying activities is very important.

Primarily, this research aimed to identify the buying behavior of furniture consumers in the period before the COVID-19 pandemic by analyzing: (1) activities that drive their decision to purchase furniture, (2) where consumers seek for information about the product, and (3) where they primarily purchase furniture.

However, recent research has shown that the buying behavior during a pandemic is, therefore, sensitive to consumer attitudes [50,51]; people's reactions to the COVID-19 pandemic vary according to personal factors, such as age $[50,52]$, while, in the context of the COVID-19 pandemic, young people are more likely to purchase online than elderly people [53].

Due to the COVID-19 pandemic, we gave additional emphasis on comparing selected consumer's activities before and during the coronavirus pandemic regarding age, especially (1) activities that drive their decision to purchase furniture, (2) where consumers seek information about the product, and (3) where they primarily purchase furniture.

\section{Materials and Methods}

\subsection{Questionnaire Design}

Based on the research objective to collect information from potential furniture consumers, a questionnaire was developed using the existing literature and based on the authors' previous research findings [3,54-58]. The questionnaire was distributed in the Croatian language and consisted of two parts. The first part contained questions about the demographic and economic characteristics of consumers, such as gender; level of education (elementary school, high school, and university); age (according to four predefined categories); and monthly household income. These variables were used as predictors of the prepurchase behavior of furniture consumers. 
The second part of the questionnaire consisted of questions related to the furniture purchase decision-making process, including the frequency of purchase planning, frequency of furniture purchase, information gathering about furniture, and characteristics.

Responses to the decision process questions were measured using multiple-item Likert scales based on Churchill's [59] observation that no single item is likely to provide a perfect representation of the general idea. Item scales were given on a scale of agreement: 1 (not important), 2 (somewhat important), 3 (neither yes nor no/indifferent), 4 (important), and 5 (very important). To avoid difficult or confusing questions, the questionnaire was pretested and revised.

\subsection{Sampling and Data Collection}

Snowball sampling as a nonprobability sampling technique was used to distribute the questionnaires. An electronic form of the questionnaire was distributed to respondents through emails and social networks. University students were the "first movers" who started the dissemination of the questionnaire. This approach was chosen because it was considered the most cost-effective for the survey, ensured data collection over a large geographical area, and allowed for a low-cost data conversion [59-61].

Based on the research objectives, two survey processes were conducted. The first survey process started in Croatia in April 2020 and ended in May 2020 and was related to respondents' purchasing behavior before and at the beginning of the COVID-19 pandemic. At that time, most people believed that the COVID-19 pandemic was a matter of a few months, that it would end in the summer of 2020, and that nothing would really change. However, in the spring of 2021, after a year of the COVID-19 pandemic, we know that things will never be the same as they were before.

To obtain information about the change in consumer purchasing behavior before and during the COVID-19 pandemic period, the second process of the survey was conducted. In the second process of the survey, we selected three questions from the first survey that we determined might have the most important differences.

1. What activities preceded your decision to purchase furniture?

2. Where do you search for information about the product you want to buy?

3. Where do you most often buy furniture?

A second survey process was conducted in March 2021 with a different sample of respondents with a similar age distribution.

In the first survey process (before the COVID-19 pandemic), 400 questionnaires were completed, while, in the second survey process, 244 questionnaires were completed.

\subsection{Data Analysis}

Data were analyzed using SPSS Statistics 25.0 software (SPSS Inc., Chicago, IL, USA) and Microsoft Excel (Microsoft EMEA, Issy-les-Moulinex, France).

Parametric methods were chosen to analyze the Likert-type data. Descriptive statistics were reported as $\mathrm{M}=$ mean and $\mathrm{SD}=$ standard deviation. The level of statistical significance was set at $\alpha=0.05$. To compare the results of two independent samples, the $t$-test was applied. If Levene's test of equality of the variances was significant, the more robust Welch's $t$-test with corrected degrees of freedom was performed instead of the regular independent samples $t$-test. In the case of more than two independent samples, a one-way ANOVA was performed. Hochberg's GT2 post hoc test was used to detect differences between the pairs of samples, which is appropriate for different sample sizes.

Spearman's rank correlation coefficient, a nonparametric measure of dependence, was used to measure the correlation between responses regarding purchase activities and furniture attributes.

A comparison of the qualitative data between two studies (between and during the COVID-19 pandemic) was processed using Pearson's chi-square test of independence to assess the significance of the frequency differences. If the assumptions underlying the chi-square test were not met, Fisher's Exact Test was performed. 


\section{Results and Discussion}

\subsection{Respondents' Profiles}

The first part of the questionnaire consisted of questions that reflected the profile of the respondents who participated in the survey. Four hundred respondents participated in the survey and answered the questionnaire. Of the 400 respondents, $68.25 \%$ were female and $31.75 \%$ were male. Both age and education were classified into four categories (Table 1 ).

Table 1. The consumer demographic characteristics.

\begin{tabular}{ccc}
\hline Gender $^{\mathbf{1}} \mathbf{( \% )}$ & Education Level $^{\mathbf{1}} \mathbf{( \% )}$ & Age Level $^{\mathbf{1}} \mathbf{( \% )}$ \\
\hline Female (68.3) & elementary school (1.8) & 18 to 24 years old (20.5) \\
male (31.7) & high school graduate (39.0) & 25 to 34 years old (38.0) \\
& college graduate (52.5) & 35 to 64 years old (39.0) \\
& graduate degree (6.8) & Older than 65 (2.5) \\
& (M.S./Ph.D.) & \\
\hline
\end{tabular}

${ }^{1}$ Percent of respondents $(\%)(N=400)$.

Most of the respondents (39\%) were between 35 and 64 years of age, followed by the $25-34$ age group (38\%), while $20.5 \%$ of the respondents were aged between 18 and 24 years. Only $2.5 \%$ of the respondents were people older than 65 . Furthermore, the educational structure was determined based on the 400 respondents. More than half $(52.5 \%)$ were individuals who had a graduate degree, followed by respondents who had a high school education (39\%). Of the total number of respondents, $6.8 \%$ were individuals with a completed master's or doctoral degree, while only $1.8 \%$ were individuals with elementary school education. Moreover, the average monthly net income per respondents household was 1100 EUR (SD = 340 EUR).

\subsection{Consumer Behavior and Preferences for Furniture Atributtes}

In the second part of the questionnaire, respondents were asked about their behaviors and preferences for furniture attributes regarding the activities that preceded their decisions about furniture purchasing.

\subsubsection{Consumer Purchasing Behavior for Furniture}

Respondents were asked to indicate the degree of importance of selected consumer behavior activities. As can be seen in Figure 1, of the 400 respondents, $62 \%$ indicated that information was very important to them before making a final decision to purchase furniture. On the other hand, only $6 \%$ of the respondents indicated that they are very well-informed about the furniture available in the market, so research activities were not necessary for them before buying furniture. From the consumer behavior factors analyzed, $47 \%$ of respondents indicated that is important not to spend much time on furniture shopping, which shows that most of the respondents will spend more time on making a decision about furniture. Moreover, $54 \%$ of the respondents will go out of their way to buy furniture at a lower price, while $32 \%$ of the respondents will wait until the product is discounted. These results show that buying furniture at a lower price or discounted products are not that important to them.

Table 2 shows how consumer differences in the demographic (age, gender, and education) and economic (monthly net income per household) categories affect consumer behaviors. Significant differences were found between some of the consumers' personal factors at an $\alpha$ of 0.05 . 


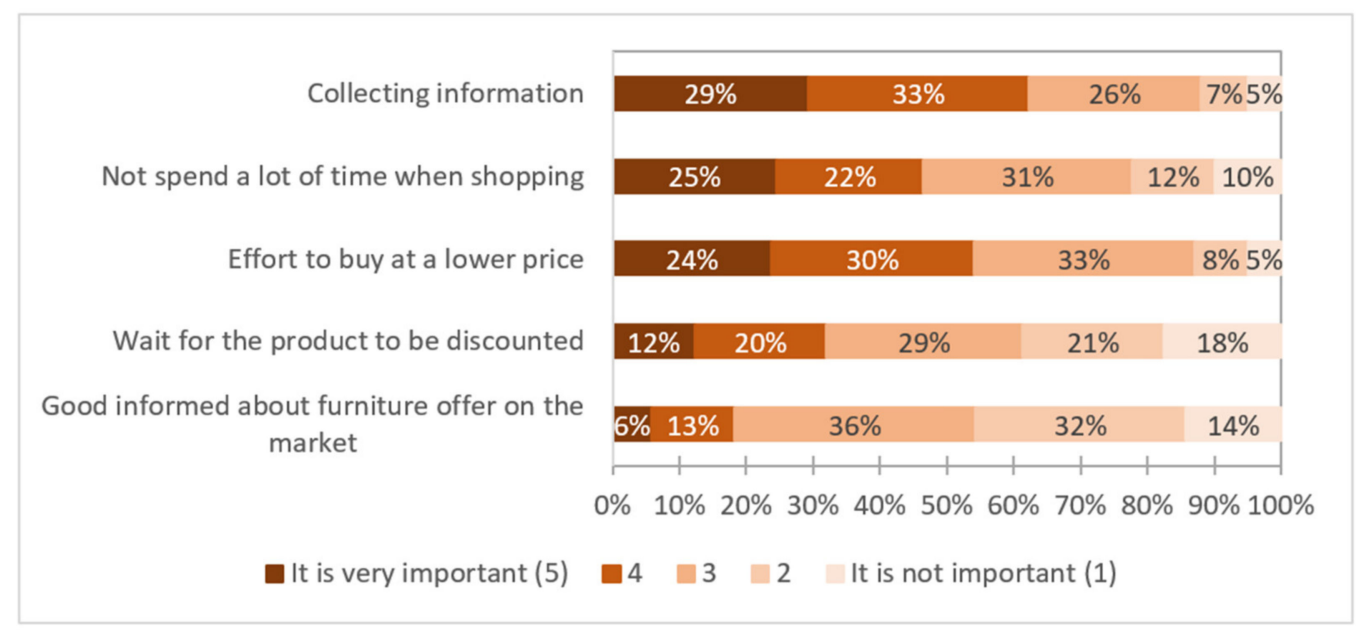

Figure 1. Consumer behavior activities for purchasing $(N=400)$.

Table 2. Consumers' personal factors and consumer behavior activities.

\begin{tabular}{cccccc}
\hline CPF & Q 16 & Q 17 & Q 18 & Q 19 & Q 20 \\
\hline Gender & 0.350 & 0.219 & 0.656 & 0.942 & $0.007^{*}$ \\
Age & 0.577 & 0.091 & 0.486 & 0.225 & $0.019^{*}$ \\
Education & $<0.001^{*}$ & $0.045^{*}$ & 0.112 & 0.261 & 0.325 \\
Household Income & 0.1 & 0.536 & 0.972 & 0.462 & $0.006^{*}$
\end{tabular}

p-values; statistically significant values are denoted by ${ }^{*} ; N=400$ respondents. Consumer behaviors: Q 16collecting information; Q 17-additional effort to buy at lower price; Q 18-not to spend lot of time when shopping; Q 19-good informed about furniture offer on the market; Q 20-wait for the product to be discounted; and $\mathrm{CPF}$ - consumer personal factors (gender, age, education, and household income).

The ANOVA results indicated that, for individuals with a higher level of education, gathering information before making a purchase decision was more important $(\mathrm{F}(3396)=9.68, p<0.001)$. Compared to male respondents $(\mathrm{M}=2.6$; $\mathrm{SD}=1.2)$, female respondents $(\mathrm{M}=3.0, \mathrm{SD}=1.3)$ indicated higher importance regarding information gathering. Waiting for the product to be discounted indicated significant differences between genders $(t(398)=2.73, p=0.007)$, age groups $(\mathrm{F}(3396)=3.34, p=0.019)$, and household income groups $(\mathrm{F}(3394)=4.24, p=0.006)$. The respondents with monthly household net incomes less than 400 EUR recorded the highest values $(M=3.4, S D=0.9)$, which means that the respondents with the lowest monthly household net incomes were more willing to wait for a product discount. The conducted results are in line with some findings of Nicholls and Bumgardner [62], who noted some sociodemographic statistical differences in preferences among wood furniture consumers. Additionally, both age and income were found to be statistically significant, with age having a stronger effect. In the same research, Nicholls and Bumgardner [62] also found that gender was not statistically significant, which was not the case in our study.

\subsubsection{Consumer Preferences for Furniture Attributes}

An analysis of the differences in preferences for specific furniture attributes provided further insight into end-user attitudes. Figure 2 shows the respondents' attitudes towards the furniture attributes of functionality, design, price, massive wood as a material, quality, price, delivery time, assembly, cleaning and maintenance, and brand. Of the furniture attributes studied, functionality had the greatest importance (67\% very important and $29 \%$ important) in the purchase decision. More than $50 \%$ of the respondents considered quality and design to be very important. Quality was very important to $58 \%$ and important to $32 \%$ of the respondents. Strong preferences for furniture design (55\% very important and $38 \%$ important) were also expressed by respondents. In general, the high proportions of positive preferences for functionality, quality, and design (with the lowest proportions of 
indifferent responses) indicated that these purchasing factors were of great importance to respondents. Similar results have been published in previous studies, with Kaputa and Šupín [63] (2010) and Kaputa et al. [7] finding that two of the most relevant purchase decision factors were quality and design. Moreover, Bumgardner and Nicholls [64] stated that design decisions will play an increasingly important role in green supply chains in the future as, in conjunction with eco-labeling, consumers can be presented with sustainability choices when making purchasing decisions.

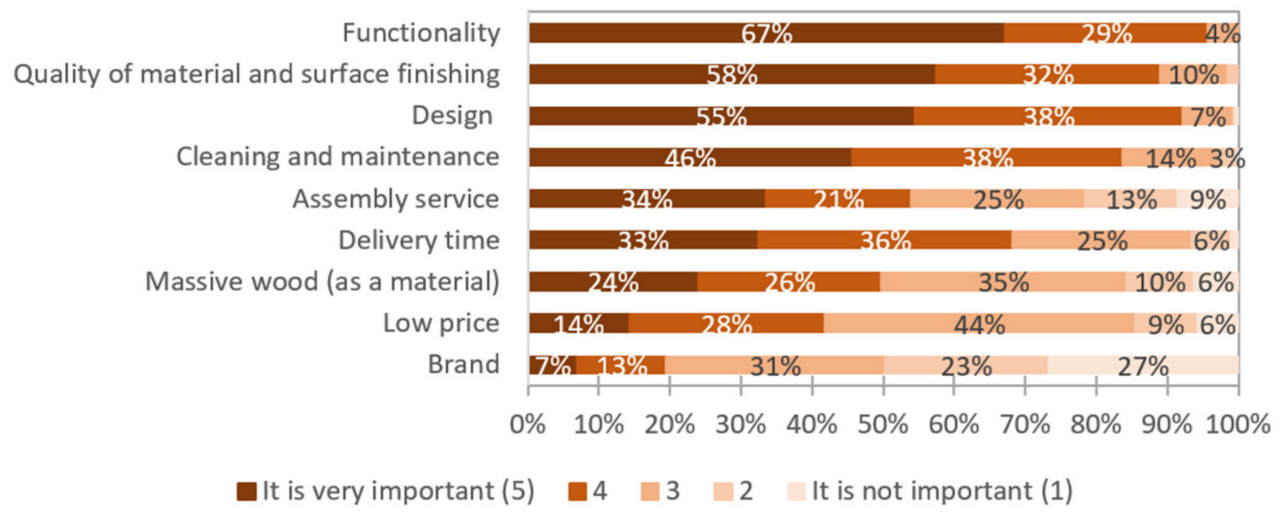

Figure 2. Consumer preferences for furniture attributes $(N=400)$.

Nevertheless, it was found that a low price and brand are not so important furniture attributes of end-users. Of the analyzed furniture attributes, brand had the least importance, with only $7 \%$ of respondents considering brand as a very important attribute. In addition, a low price was very important only to $14 \%$ of the respondents. This is in line with the findings of Khojasteh-Khosro et al. [4], who noted that product quality was more important than price in consumers' buying decision process regarding lightweight furniture.

An analysis of the differences in preferences for specific furniture attributes as a function of consumer demographic and economic characteristics provided further insight into respondents' attitudes (Table 3).

Table 3. Consumer's personal factors and consumer preferences.

\begin{tabular}{cccccccccc}
\hline CPF & Q 21 & Q 22 & Q 23 & Q 24 & Q 25 & Q 26 & Q 27 & Q 28 & Q 29 \\
\hline Gender & 0.322 & $0.044^{*}$ & $<0.001^{*}$ & 0.302 & 0.122 & $0.046^{*}$ & 0.069 & 0.505 & $<0.001^{*}$ \\
Age & 0.747 & 0.388 & $0.013^{*}$ & 0.082 & 0.201 & 0.108 & 0.125 & $0.026^{*}$ & 0.155 \\
Education & $0.033^{*}$ & 0.634 & $0.034^{*}$ & $0.020^{*}$ & 0.459 & 0.100 & 0.084 & 0.229 & 0.664 \\
Household Income & $0.009 *$ & 0.894 & 0.243 & 0.141 & 0.953 & 0.283 & 0.748 & 0.079 & 0.107 \\
\hline
\end{tabular}

$p$-values; statistically significant values are denoted by ${ }^{*} ; N=400$ respondents. Furniture attributes: Q 21-low price; $\mathrm{Q} 22-$ functionality; Q 23-design; Q 24-massive wood (as a material); Q 25-quality of material and surface finishing; $Q$ 26-delivery time; Q 27-assembly service; Q 28-brand; Q 29-cleaning and maintains; and CPF—consumer personal factors (gender, age, education, and household income).

Of the furniture attributes analyzed, functionality (Welch's $t(225)=2.03, p=0.044)$, design (Welch's $t(204)=3.68, p<0.001)$, delivery time $(t(398)=2.00, p=0.046)$, and cleaning and maintenance $(t(398)=5.19, p<0.001)$ were significantly more important to female than to male respondents. Additionally, female respondents rated functionality as the most important attribute. This is consistent with the findings of Lihra and Graf [65] and Oblak et al. [56], who discussed that the decision-making process also depends on gender, as females discover the need for new furniture earlier and more frequently than males. Regarding respondents' age categories, significant differences were found for design $(\mathrm{F}(3396)=3.62, p=0.013)$ and brand $(\mathrm{F}(3396)=3.12, p=0.026)$. Post-hoc comparisons using Hochberg's GT2 test indicated that older respondents (65 years or more) $(\mathrm{M}=3.8$, $\mathrm{SD}=1.3$ ) rated design as significantly less important than the other age groups. Significant 
differences were also found in relation to the brand between respondents in the 25-34 age category $(\mathrm{M}=2.3, \mathrm{SD}=1.1)$ and respondents in the 35-64 age category $(\mathrm{M}=2.7$, $\mathrm{SD}=1.2$ ). However, for less-educated individuals (with low-paying jobs), low price was very important, but its importance decreased with higher education $(F(3396)=2.95$, $p=0.033$ ). Interestingly, for those with a M.S. or Ph.D., low price was also important. Regarding design, the less-educated respondents (elementary school) $(\mathrm{M}=3.7, \mathrm{SD}=1.5)$ found design significantly less important than the other educational groups $(\mathrm{F}(3396)=2.92$, $p=0.034)$. Additionally, high school respondents rated massive wood as a more important $(\mathrm{M}=3.7, \mathrm{SD}=1.1)$ furniture attribute than graduate degree respondents $(\mathrm{M}=3.4, \mathrm{SD}=1.2)$ $(\mathrm{F}(3396)=3.30, p=0.020)$.

\subsection{Additional Purchasing Activities Influencing Furniture Purchasing Decisions}

To enrich this study, additional activities that consumers engage in during the purchase period, such as how they gather information about the furniture they are interested in, the place where they buy furniture, and additional services, were studied (Figure 3).

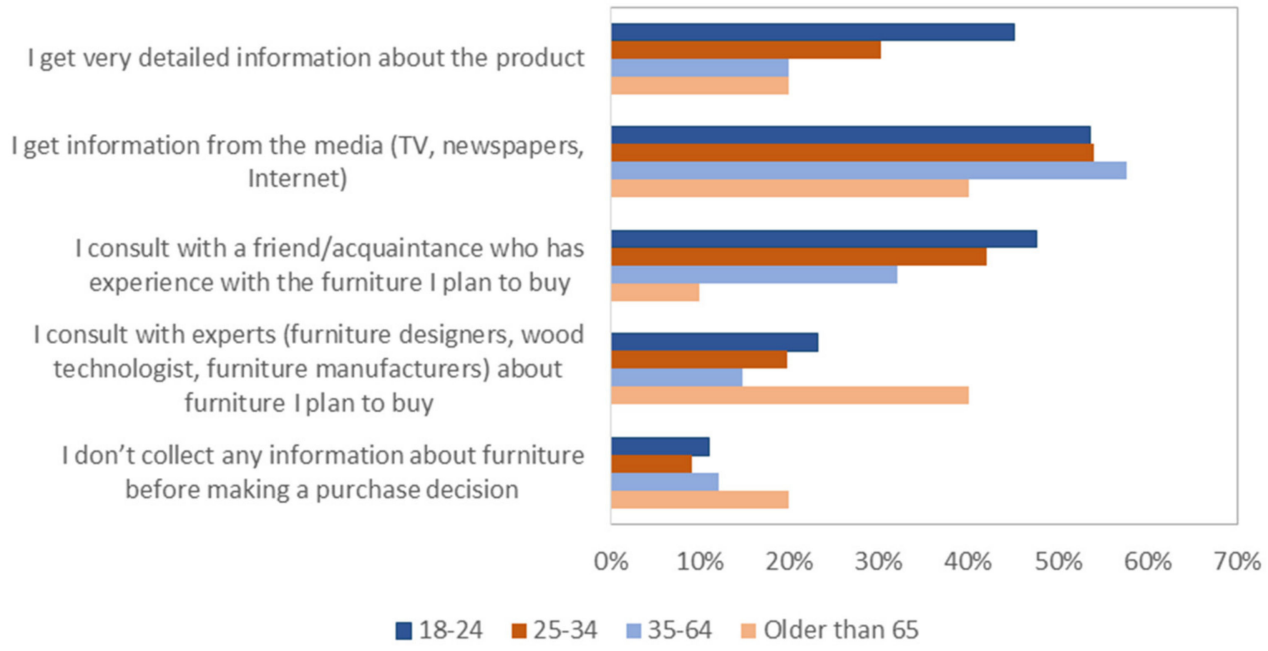

Figure 3. Consumer ways of collecting information regarding age $(N=400)$.

Respondents of different age groups and education differed in the way they obtained information about the product before making a final decision about a furniture purchase. There was less difference between the genders and average monthly household incomes. Young respondents, from 18 to 24 years, were more likely to obtain detailed information about the products they wanted to buy ( $45 \%$ of the respondents) than older respondents ( $20 \%$ of the respondents). However, respondents who were older than 65 were more likely to consult with experts such as furniture designers, wood technologists, and furniture manufacturers about the furniture they planned to buy ( $40 \%$ of the respondents) compared to young respondents ( $23 \%$ of the respondents). An interesting finding was that $48 \%$ of young respondents (18-24) would consult with a friend about the furniture they wanted to buy, while this was only the case for $10 \%$ of respondents older than 65 years old.

Overall, regardless of the age category, respondents tried to gather as much information as possible by using different sources of information (experts, friends/acquaintances, and Internet-based technologies) before making a furniture purchase decision. Within different sources of information, information gathering through the media (including the Internet) was found to be the most common. This is partly in line with Perry's [7] conclusion that consumers start their purchase process through an online search engine.

As can be seen in Figure 4 , the more-educated respondents ( $>50 \%$ of the respondents) stated that they collected detailed information about the product they wanted to buy. The media was noted as the most common way of collecting information by the respondents having graduate degree diplomas and a M.s./Ph.D. 


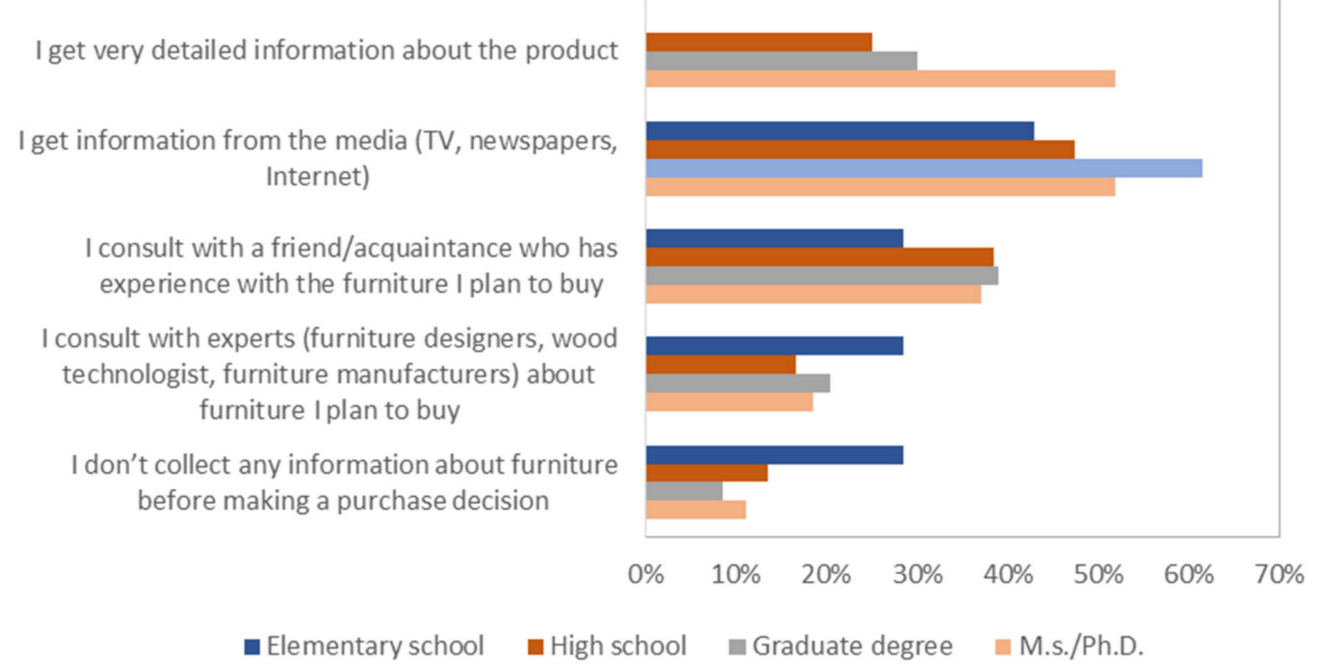

Figure 4. Consumer way for collecting information regarding education $(N=400)$.

Regarding the level of comparison between the products of different manufacturers before making a purchase decision, the same percentage of the respondents $(46 \%$ out of 400 respondents) indicated that they try to compare products of several furniture manufacturers before making a purchase decision, or they compare products between the furniture manufacturers they trust the most. However, only $8 \%$ of respondents do not compare products from different manufacturers during the purchasing decision, because they are always loyal to one manufacturer. Furthermore, Figure 5 shows that $46 \%$ of the respondent stated that they will make a purchase decision for furniture regardless of discount promotions, while $24 \%$ of the respondent make purchase decisions based on discount information about specific furniture.

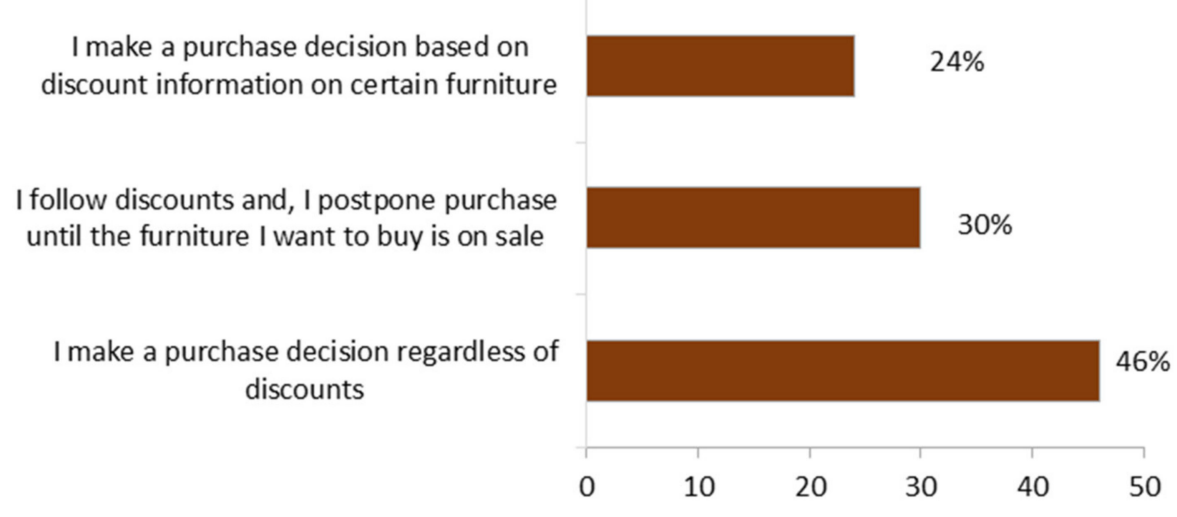

Figure 5. Consumer decisions about furniture based on discount information $(N=400)$.

\subsection{Relationship between Thinking about Purchasing Furniture and Purchasing Furniture}

We wanted to find out how the frequency of thinking about buying furniture influences consumer behaviors and preferences for furniture attributes. The ANOVA showed a significant difference in terms of information gathering prior to a furniture purchase $(\mathrm{F}(4395)=4.92, p=0.001)$ between respondents who thought about buying furniture less (one to two times per year) $(\mathrm{M}=3.4, \mathrm{SD}=1.1)$ and those who thought about it more (3-5 times, $6-10$, and more than 10 times per year). The frequency of thinking about buying furniture implied a significant difference in the importance of furniture attributes among the respondents. A significant difference was found in functionality $(\mathrm{F}(4395)=1.88, p=0.014)$ between respondents who think about buying furniture less (one to two times a year, $\mathrm{M}=4.5, \mathrm{SD}=0.6)$ and more ( $3-5$ times a year, $\mathrm{M}=4.7, \mathrm{SD}=0.5)$. The more often consumers 
thought about purchasing furniture in the past year, the more important functionality of the furniture was to them. There was a significant difference $(\mathrm{F}(4395)=4.23, p=0.004)$ between respondents who thought about buying furniture more often (3-5 times a year, $\mathrm{M}=2.9, \mathrm{SD}=0.9$ ), less often (one to two times a year, $\mathrm{M}=2.7, \mathrm{SD}=1.1$ ) or never $(\mathrm{M}=2.4$, $\mathrm{SD}=1.1$ ). The more often consumers bought furniture in the past years, the more important information about furniture was to them.

Moreover, Spearman's rank-order coefficient confirmed a significant positive correlation $\left(\mathrm{r}_{\mathrm{S}}(7)=0.482, p<0.001\right)$ between thinking about purchasing furniture and buying furniture in the past year (Figure 6).

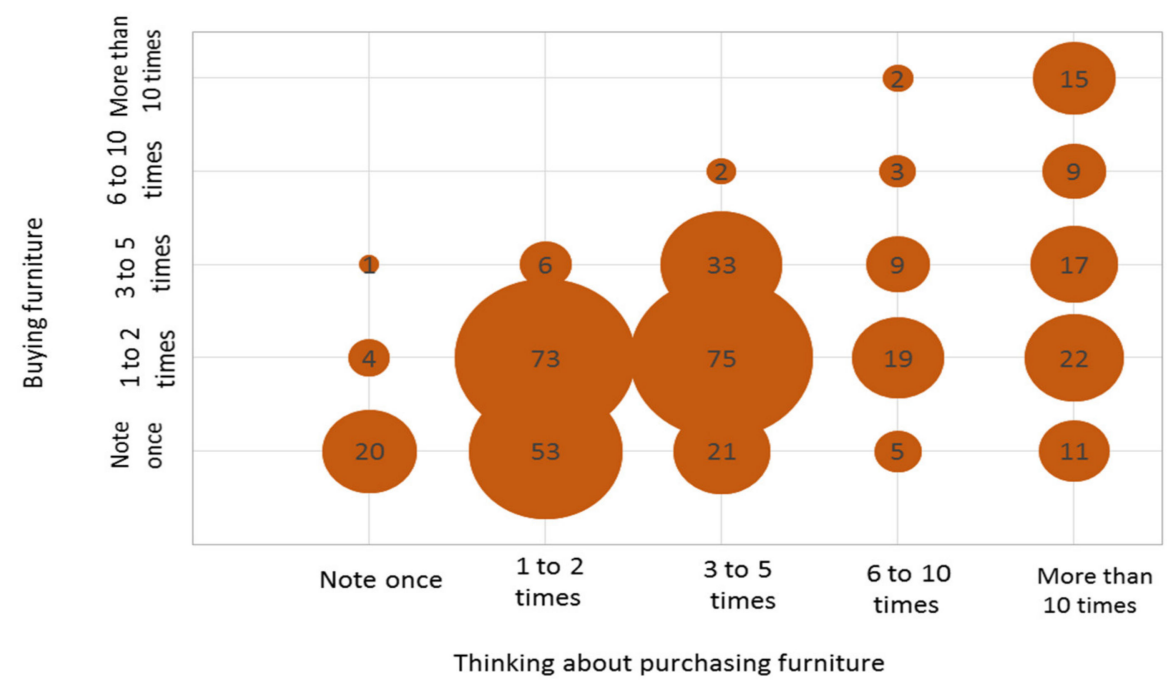

Figure 6. Correlation between the frequencies of thinking about and buying furniture $(N=400)$.

Spearman's rank-order coefficient confirmed a significant low, positive correlation $\left(r_{S}(400)=0.128, p=0.010\right)$ between the importance of gathering information and the frequency of buying furniture (Figure 7). The conducted results can be supported by the findings of Liang [66] that the higher the level of consumers' product knowledge, the higher the tendency of impulse purchasing behavior.

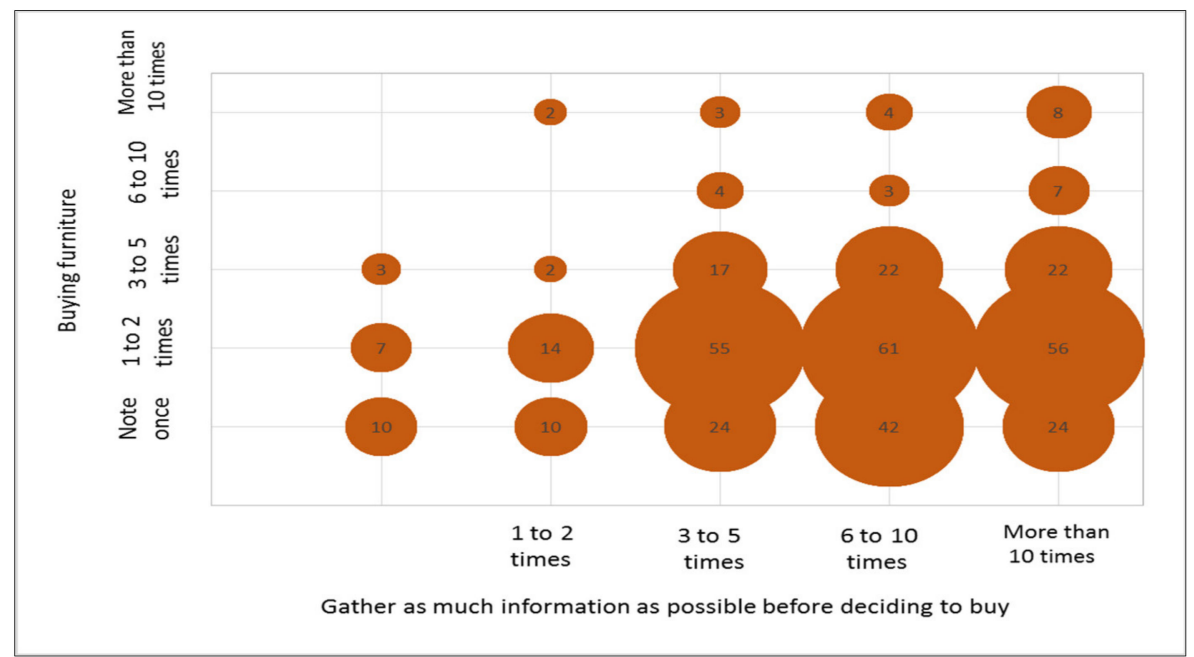

Figure 7. Correlation between gathering information and buying furniture $(N=400)$.

In addition, we considered the correlation between consumer behavior activities and consumer preferences for furniture attributes. Only at least moderately strong positive correlations $\left(r_{S}>0.4\right)$ were reported. Spearman's rank-order coefficient confirmed a significant 
positive correlation $\left(\mathrm{r}_{\mathrm{S}}(400)=0.589, p<0.001\right)$ between the effort spent to purchase the product at a lower price and waiting for a discount on the product. Spearman's rank-order coefficient confirmed a significant positive correlation $\left(\mathrm{r}_{\mathrm{S}}(400)=0.469, p<0.001\right)$ between massive wood material and quality of material and surface finishing.

\subsection{Comparison of Consumer Activity before and during the COVID-19 Pandemic}

The coronavirus pandemic is teaching us all a hard lesson in resilience and adaptability, forcing individuals and organizations of all sizes to confront a deep, ongoing crisis that threatens our lives and livelihoods. We all face new challenges in the new normal, so we were interested in comparing selected three questions about consumer activities before and during the COVID-19 pandemic. Respondents in the first survey phase of analyses (before COVID-19 pandemic) and in the second phase of the analyses (during COVID-19 pandemic) gave similar responses regarding (1) activities that preceded their decision for buying furniture, as differences in the frequencies were not statistically significant. More specifically, more than $60 \%$ of the respondents indicated that they study all the options in detail before making a final decision about buying furniture before and during COVID-19 time. In contrast, less than $20 \%$ of respondents stated that they do not plan to buy furniture in advance, but do so as soon as the need for new furniture arises (Figure 8).

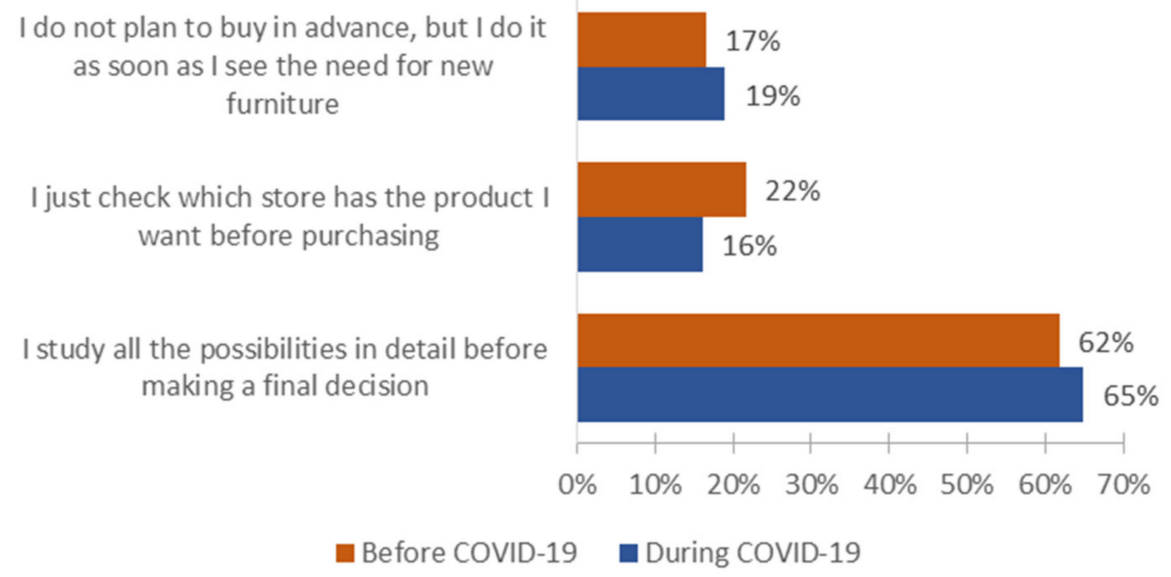

Figure 8. Comparison of consumer activities preceding the decision for buying furniture before $(N=400)$ and during the COVID-19 pandemic $(N=244)$.

\subsection{Correlation between Information Gathering and Buying Furniture $(N=400)$}

When asked where respondents look for information about the products they plan to buy, the main difference between before and during the COVID-19 pandemic was in the response "Asking my friends/acquaintances who have experience with the furniture manufacturer", with 26\% before the COVID-19 pandemic and only 2\% during COVID- 19 .

In addition, no significant difference was found between the other ways of finding out about products, such as on the furniture manufacturer's website, on the furniture seller's website, by watching commercials on TV, in furniture catalogs or flyers, and in person with the furniture manufacturer or seller (Figure 9).

As shown in Figure 10, the responses to the question "Where do you most often buy furniture?" differed significantly between before and during the COVID-19 pandemic $(\chi 2(3, n=644)=43.213, p<0.001)$. The main difference was in the answer "I buy online" (before the COVID-19 pandemic was 6.5\% and during the COVID-19 pandemic was 14.3\%). This can be supported by the United Nation Conference on Trade and Development (UNCTAD) study, which found that the COVID-19 pandemic has forever changed the way consumers shop online. The study showed that more than half of respondents (out of nearly 3700 consumers in nine countries) reported that they were shopping more online. 
Additionally, product purchases were found to be up nearly $10 \%$ for information and communications technology products, education, furniture, and personal care.

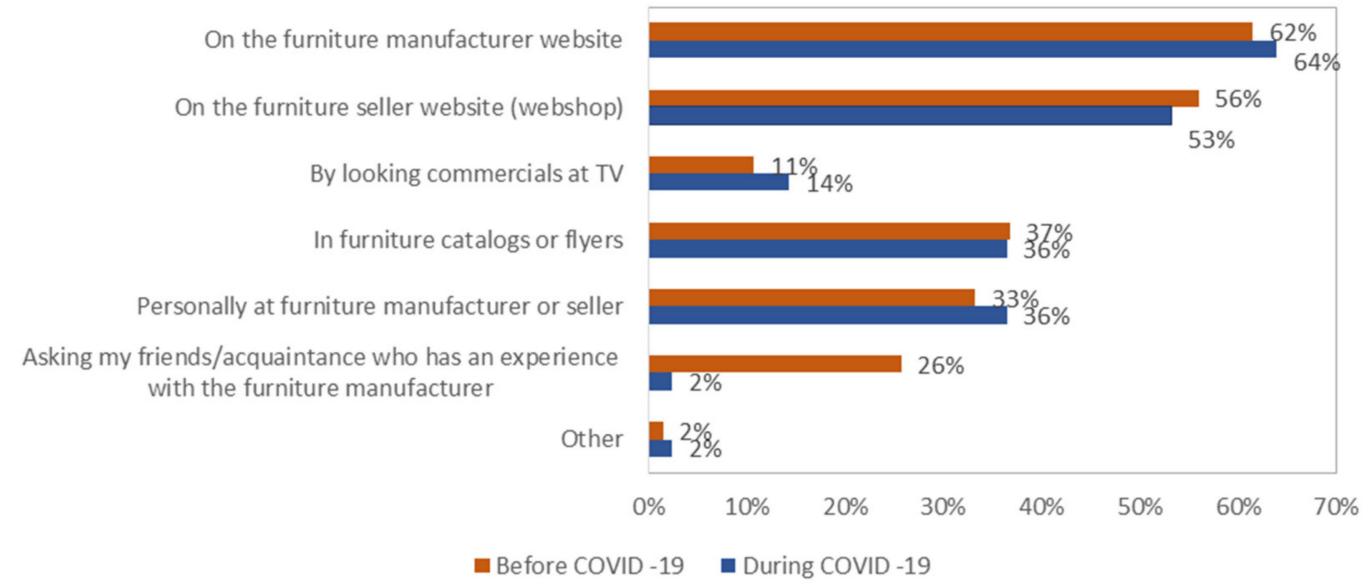

Figure 9. Comparison of the locations used to search for information about furniture before $(N=400)$ and during the COVID-19 pandemic $(N=244)$.

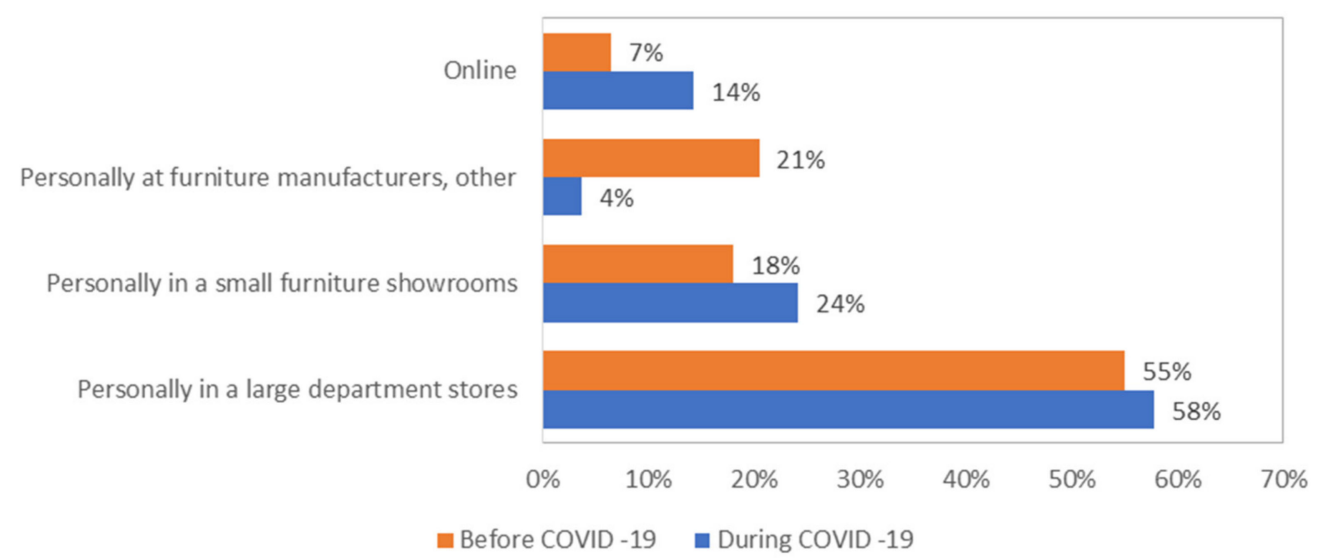

Figure 10. Comparison of the locations for purchasing furniture before $(N=400)$ and during the COVID-19 time $(N=244)$.

It is interesting to note that, as shown in Figure $11,60 \%$ of the older respondents (older than 65) indicated that, in the time before the COVID-19 pandemic, the most common place to buy furniture was in person at a large department store, while during the COVID-19 pandemic, none of the respondents noted this. In contrast, $50 \%$ of the respondents older than 65 stated that they purchased furniture online during the COVID-19 pandemic, while before the COVID-19 pandemic, none of the respondents noted this.

Additionally, the results differed significantly between age groups before COVID-19 (Fisher's Exact Test $=16.981, p=0.029)$ and, also, during COVID-19 $(\chi 2(9, n=400)=28.182$, $p=0.001)$. 


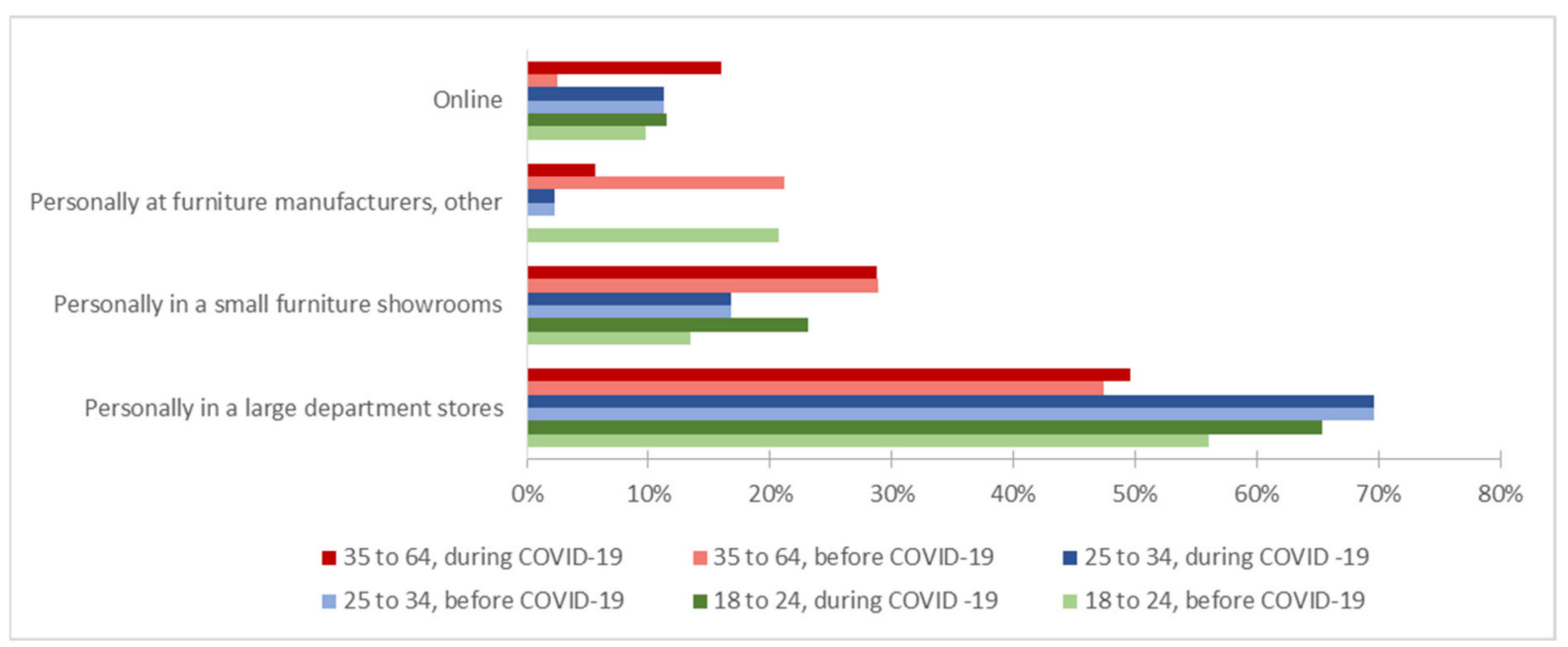

Figure 11. Comparison of the places for furniture purchasing regarding the age category before $(N=400)$ and during the COVID-19 time $(N=244)$.

\section{Conclusions}

Studying consumer behaviors is important, because it helps stakeholders to understand the needs and expectations of the consumers. Primarily, this study provided information about the buying behaviors of furniture consumers in the period before the COVID-19 pandemic.

The results of consumer buying behaviors for furniture showed that buying furniture at a lower price or discounted products are not that important. Compared to male respondents, female respondents indicated a higher importance regarding information gathering. Waiting for a discounted product showed significant differences between genders, age groups, and household income groups. The respondents with lower monthly household net incomes were more willing to wait for a product discount. In terms of furniture attributes, the high proportions of positive preferences for functionality, quality, and design showed that these purchase factors are very important for consumers in the purchase decision process, especially to female end-users.

In terms of respondents' age categories, older respondents (65 years or older) rated design as less important than the other age groups. However, for less-educated people (with low-paying jobs), a low price was very important. Interestingly, a low price was also important to people with M.S. or Ph.D. degrees. Respondents of different age groups and education levels differed in the way they learned about a product before making a final decision about furniture purchases. Young respondents were more likely to get detailed information about the products they wanted to buy, while older respondents were more likely to consult experts, such as furniture designers, wood technologists, and furniture manufacturers. Overall, respondents, regardless of age category, tried to obtain as much information as possible by using different sources of information (experts, friends/acquaintances, and the media) before making a purchase decision for furniture. However, the more-educated respondents gathered detailed information about the products they were willing to buy. This study showed that there was a positive relationship between consumers thinking about the intention to buy furniture and buying furniture. In addition, a positive correlation between thinking about buying furniture and buying furniture in the past year was noted, while there was a low positive correlation between the importance of obtaining information and the frequency of buying furniture. The results also emphasized a positive correlation between making an effort to buy a product at a lower price and waiting for a discount on the product.

The COVID-19 pandemic has made consumer behaviors more complex, and consumer experiences based on personal needs, desires, and experiences are becoming more directly linked to being in new environments. This is one of the reasons why this research addi- 
tionally provides information about furniture consumer buying behaviors in the periods before and during the coronavirus pandemic.

The study showed that there was no difference in consumers' activities regarding conducting information before making a final decision about buying furniture before and during the COVID-19 time. The main difference between before and during the COVID-19 pandemic time was about comparison of locations used to search for information about furniture. Comparisons of locations for purchasing furniture differed before and during the COVID-19 pandemic, especially online purchasing (before the COVID-19 pandemic was $6.5 \%$ and during the COVID-19 pandemic was $14.3 \%$ ). In the time before the COVID19 pandemic, the older respondents were buying furniture mostly in person at a large department store, while during the COVID-19 pandemic time, they more often purchased furniture online.

Furniture manufactures could use these results to create specific offers for different consumer segments according to their preferences, which could lead to a higher appreciation of wood-based materials and wood-engineered products. Company agility allows to take bold, decisive action. It gives the freedom and flexibility to pursue solutions outside the box and, also, to create an offering that is distinctly different from the competition. When companies know when and what to communicate and how to use the information gathered from marketing research, it can help them to improve their actions at the market and build inimitable competitive advantages. In addition, these findings offer insights into future design and building communication to better meet the information needs of different types of consumers and to more broadly increase the acceptance and appeal of wood furniture in society in the spirit of sustainable and bio-based circular economy. In addition, this era offers many opportunities for organizations to adept marketing strategies and policies.

Our future work will be continuously monitoring consumers purchasing behaviors for wooden furniture while also giving emphasis to their wellbeing. We also want to follow if companies collect feedback, since it keeps them in tune with customers. Curious companies and organizations take action on the feedback they gather at twice the rate as companies that stick to tried-and-true methods.

Author Contributions: Conceptualization, A.P.B., P.G., T.V. and M.K.K.; methodology, P.G., A.P.B. and M.K.K.; software, P.G.; validation, A.P.B., P.G. and M.K.K.; formal analysis, P.G.; investigation, T.V., P.G., M.K.K. and A.P.B.; resources, M.K.K., T.V. and A.P.B.; data curation, P.G., A.P.B. and M.K.K.; writing-original draft preparation, A.P.B., T.V., P.G. and M.K.K.; writing-review and editing, M.K.K., P.G. and A.P.B.; visualization, P.G., A.P.B. and M.K.K.; supervision, A.P.B., P.G. and M.K.K.; project administration, T.V. and M.K.K.; and funding acquisition, P.G. and A.P.B. All authors have read and agreed to the published version of the manuscript.

Funding: This research was funded by Slovenian Research Agency within the framework of the programs P4-0015 and P4-0059. Andreja Pirc Barčić and Tihana Vergot wish to thank the University of Zagreb, Faculty of Forestry and Wood Technology Fund for scientific and professional work for the financial support.

Data Availability Statement: The data presented in this article are available on request from the corresponding author. The data are not publicly available due to privacy restrictions.

Conflicts of Interest: The authors declare no conflict of interest. The funders had no role in the design of the study; in the collection, analyses, or interpretation of the data; in the writing of the manuscript; or in the decision to publish the results.

\section{References}

1. Van Raaij, W.F. Understanding Consumer Financial Behavior: Money Management in an Age of Financial Illiteracy; Palgrave Macmillan: London, UK, 2016.

2. Kotler, P. Marketing Management, Analysis, Planning, Implementation and Control, 8th ed.; Prentice Hall: Upper Saddle River, NJ, USA, 1991.

3. Oblak, L.; Glavonjić, B.; Barčić, A.P.; Govedič, T.B.; Grošelj, P. Preferences of Different Target Groups of Consumers in Case of Furniture Purchase. Drv. Ind. 2020, 71, 79-87. [CrossRef] 
4. Khojasteh-Khosro, S.; Shalbafan, A.; Thoemen, H. Consumer behavior assessment regarding lightweight furniture as an environmentally-friendly product. Wood Mater. Sci. Eng. 2020, 1-10. [CrossRef]

5. Olšiaková, M.; Loučanová, E.; Paluš, H. Monitoring changes in consumer requirements for wood products in terms of con-sumer behavior. Acta Fac. Xylologiae Zvolen 2016, 58, 137-147. [CrossRef]

6. Shahsavar, T.; Kubeš, V.; Baran, D. Willingness to pay for eco-friendly furniture based on demographic factors. J. Clean. Prod. 2020, 250, 119466. [CrossRef]

7. Perry, D. Google Opens Playbook to Share ZMOT Insights. Furnit. Today 2013, 27.

8. Ponder, N. Consumer Attitudes and Buying Behavior for Home Furniture; Mississippi State University: Starkville, MS, USA, 2013.

9. Cortés-Chávez, F.; Chaurand, R.Á.; Âvila, I.C.L. Effect of Subjective Evaluation Factors on the Buying Decision of Residential Furniture. Procedia Manuf. 2015, 3, 6467-6474. [CrossRef]

10. Høibø, O.; Hansen, E.; Nybakk, E.; Nygaard, M. Preferences for Urban Building Materials: Does Building Culture Background Matter? Forests 2018, 9, 504. [CrossRef]

11. Dhar, R. Consumer Preference for a No-Choice Option. J. Consum. Res. 1997, 24, 215-231. [CrossRef]

12. Ashman, R.; Solomon, M.R.; Wolny, J. An old model for a new age: Consumer decision making in participatory digital culture. J. Cust. Behav. 2015, 14, 127-146. [CrossRef]

13. Weilbacher, W.M. Point of View: Does Advertising Cause a 'Hierarchy of Effects'? J. Advert. Res. 2001, 41, 19-26. [CrossRef]

14. Edbring, E.G.; Lehner, M.; Mont, O. Exploring consumer attitudes to alternative models of consumption: Motivations and barriers. J. Clean. Prod. 2016, 123, 5-15. [CrossRef]

15. Shen, J. Social comparison, social presence, and enjoyment in the acceptance of social shopping websites. J. Electron. Commer. Res. 2012, 13, 198-212.

16. Park, H.; Cho, H. Social network online communities: Information sources for apparel shopping. J. Consum. Mark. 2012, 29, 400-411. [CrossRef]

17. Sinclair, S.A.; Hansen, B.G. The relationship between purchase decisions and quality assessment of office furniture. Wood Fiber Sci. 2007, 25, 142-152.

18. Schiffman, L.G.; Kanuk, L.L. Consumer Behaviour, 8th ed.; Prentice Hall: Upper Saddle River, NJ, USA, 2004.

19. Nicholls, D.L.; Stiefel, M.C. Market Opportunities for Kitchen Cabinets Made from Alaska Hardwoods: A Synthesis and Review of Recent Research; U.S. Department of Agriculture, Forest Service: Portland, OR, USA, 2007.

20. Hall, A.; Towers, N.; Shaw, D.R. Understanding how Millennial shoppers decide what to buy. Int. J. Retail. Distrib. Manag. 2017, 45, 498-517. [CrossRef]

21. Bednarik, E.; Pakainé Kováts, J. Consumer behaviour model on the furniture market= Vásárlói magatartásmodell a bútorpi-acon. Acta Silv. Lignaria Hung. 2010, 6, 75-88.

22. Al-Azzam, A.F.M.; Fattah, M. Evaluating Effect of Social Factors Affecting. Consumer Behavior in Purchasing Home Fur-nishing Products in Jordan. Br. J. Mark. Stud. 2014, 2, 80-94.

23. Zwierzyński, P. The determinants of consumer behaviours in the furniture market. Ann. Mark. Manag. Econ. 2017, 3, 131-143. [CrossRef]

24. Dušak, M.; Jelačić, D.; Barčić, A.P.; Novakova, R. Improvements to the Production Management System of Wood-processing in Small and Medium Enterprises in Southeast Europe. Bioresources 2017, 12, 3303-3315. [CrossRef]

25. Gupta, A.; Su, B.-C.; Walter, Z. An Empirical Study of Consumer Switching from Traditional to Electronic Channels: A PurchaseDecision Process Perspective. Int. J. Electron. Commer. 2004, 8, 131-161. [CrossRef]

26. Flavián, C.; Gurrea, R.; Orús, C. Combining channels to make smart purchases: The role of webrooming and showrooming. J. Retail. Consum. Serv. 2020, 52, 101923. [CrossRef]

27. Goraya, M.A.S.; Zhu, J.; Akram, M.S.; Shareef, M.A.; Malik, A.; Bhatti, Z.A. The impact of channel integration on consumers' channel preferences: Do showrooming and webrooming behaviors matter? J. Retail. Consum. Serv. 2020, 52, 102130. [CrossRef]

28. Voramontri, D.; Klieb, L. Impact of Social Media on Consumer Behaviour. Int. J. Inf. Decis. Sci. 2019, 11, 1-25. [CrossRef]

29. Cao, L.; Li, L. The Impact of Cross-Channel Integration on Retailers' Sales Growth. J. Retail. 2015, 91, 198-216. [CrossRef]

30. Waswo, A. Housing in Postwar Japan-A Social History; Routledge: London, UK, 2013.

31. Husein, H.A. Multifunctional Furniture as a Smart Solution for Small Spaces for the Case of Zaniary Towers Apart-ments in Erbil City, Iraq. International Transaction. J. Eng. Manag. Appl. Sci. Technol. 2021, 12. [CrossRef]

32. Aras, A.; Özdemir, İ. Comparing furniture preference of housing living spaces of housing users from different so-cio-economic status. Online J. Art Design 2017, 5, 46-60.

33. Roos, A.; Nyrud, A.Q. Description of green versus environmentally indifferent consumers of wood products in Scandinavia: Flooring and decking. J. Wood Sci. 2008, 54, 402-407. [CrossRef]

34. Guzel, T.A. Consumer attitudes toward preference and use of wood, woodenware, and furniture: A sample from Kayseri, Turkey. BioResources 2020, 15, 28-37.

35. Muhammad, A.; Taylor, A. Implications of COVID-19 on Tennessee Exports of Forest Products (No. 2325-2020-597); Institute of Agriculture, The University of Tennessee: Knoxville, TN, USA, 2020.

36. U.S. Census Bureau (Census). USA Trade Online. 2020. Available online: https:/ / usatrade.census.gov/ (accessed on 6 June 2021 ).

37. Jackson, J.K.; Schwarzenberg, A.B.; Weiss, M.A.; Nelson, R.M. Global Economic Effects of COVID-19. Congression-al Research Service; CRS Report R46270; Library of Congress: Washington, DC, USA, 2020. 
38. United Nations and the Food; Agriculture Organization of the United Nations. Forest Products Annual Market Review, 2019-2020; United Nations Publications: Geneva, Switzerland, 2020.

39. IndexBox. EU-Wooden Furniture of a Kind Used in the Bedroom-Market Analysis, Forecast, Size, Trends and In-Sights. 2021. Available online: https:/ / www.indexbox.io/store/eu-wooden-furniture-of-a-kind-used-in-the-bedroom-market-reportanalysis-and-forecast-to-2020/ (accessed on 15 June 2021).

40. Hayes, S.; Morgan, T.A. Forest Products: Montana Wood Products in the Time of COVID-19. Mont. Bus. Q. 2020, $58,35-37$.

41. Shoji, Y.; Nakao, N.; Ueda, Y.; Kakizawa, H.; Hirai, T. Preferences for certified forest products in Japan: A case study on interior materials. For. Policy Econ. 2014, 43, 1-9. [CrossRef]

42. Aruna, P.B.; Laarman, J.G.; Araman, P.A.; Cubbage, F.W. An analysis of wood pellets for export: A case study of Sweden as an importer. For. Prod. J. 1997, 47, 49-52.

43. Nabuurs, G.J.; Sikkema, R. International Trade in Wood Products: Its Role in the Land Use Change andForestry Carbon Cycle. Clim. Chang. 2001, 49, 377-395. [CrossRef]

44. Statistical Yearbook of the Republic of Croatia, Croatian Bureau of Statistics. Available online: https://www.dzs.hr/Hrv_Eng/ ljetopis/2016/sljh2016.pdf (accessed on 25 March 2021).

45. Statistical Information, Croatian Bureau of Statistics. Available online: https://www.dzs.hr/Hrv_Eng/StatInfo/pdf/StatInfo202 0.pdf (accessed on 26 March 2021).

46. Centre for European Policy Studies. The EU Furniture Market Situation and a Possible Furniture Products Initiative, European Commission. Available online: https://www.ceps.eu/system/files/Final\%20report_en.pdf (accessed on 21 March 2021).

47. Statistical Yearbook of the Republic of Croatia, Croatian Bureau of Statistics. Available online: https://www.dzs.hr/Hrv_Eng/ ljetopis/2018/sljh2018.pdf (accessed on 25 March 2021).

48. Solomon, M.R. Consumer Behaviour: A European Perspective, 3rd ed.; Pearson Education: Edinburg, UK, 2010.

49. Bamossy, G.J.; Solomon, M.R. Consumer Behaviour: A European Perspective, 6th ed.; Pearson Education: Manchester, UK, 2016.

50. Meyer, S. Understanding the COVID-19 Effect on Online Shopping Behaviour. Big Commer. 2020, 2, 1-16.

51. Savarese, M.; Castellini, G.; Morelli, L.; Graffigna, G. COVID-19 disease and nutritional choices: How will the pandemic reconfigure our food psychology and habits? A case study of the Italian population. Nutr. Metab. Cardiovasc. Dis. 2021, 31, 399-402. [CrossRef] [PubMed]

52. Hesham, F.; Riadh, H.; Sihem, N. What Have We Learned about the Effects of the COVID-19 Pandemic on Consumer Behavior? Sustainability 2021, 13, 4304. [CrossRef]

53. Gao, X.; Shi, X.; Guo, H.; Liu, Y. To buy or not buy food online: The impact of the COVID-19 epidemic on the adoption of e-commerce in China. PLoS ONE 2020, 15, e0237900. [CrossRef]

54. Lemon, K.N.; Verhoef, P.C. Understanding Customer Experience Throughout the Customer Journey. J. Mark. 2016, 80, 69-96. [CrossRef]

55. Perić, I.; Bičanić, K.; Pirc, A.; Ojurović, R.; Grladinović, T. Analiza zadovoljstva kupaca namještajem. Drv. Ind. 2010, 61, 251-258.

56. Oblak, L.; Barčić, A.P.; Klarić, K.; Kuzman, M.K.; Grošelj, P. Evaluation of Factors in Buying Decision Process of Furniture Consumers by Applying AHP Method. Drv. Ind. 2017, 68, 37-43. [CrossRef]

57. Kaputa, V.; Barčić Pirc, A.; Mat'ova, H.; Motik, D. Consumer Preferences for Wooden Furniture in Croatia and Slovakia. Bioresources 2018, 13, 6280-6299. [CrossRef]

58. Jošt, M.; Oblak, L.; Perić, I.; Barčić, A.P.; Nosál'ová, M.; Kaputa, V. Changes in Customer Preferences for Furniture in Slovenia. Drv. Ind. 2020, 71, 149-156. [CrossRef]

59. Churchill, G.A., Jr. A Paradigm for Developing Better Measures of Marketing Constructs. J. Mark. Res. 1979, 16, 64-73. [CrossRef]

60. Dillman, D.A. Mail and Internet Surveys: The Tailored Design Method; John Wiley and Sons: New York, NY, USA, 2000.

61. Zahs, D.; Baker, R. Telephone and Mail Surveys: Advantages and Disadvantages of Each; Market Strategies Inc.: Livonia, MI, USA, 2007.

62. Nicholls, D.; Bumgardner, M. Evaluating selected demographic factors related to consumer preferences for furniture from commercial and from underutilized species. For. Prod. J. 2007, 57, 79-82.

63. Kaputa, V.; Šupín, M. Consumer preferences for furniture. In Proceedings of the 3rd International Scientific Conference-Wood Processing and Furniture Manufacturing, Vyhne, Slovakia, 6-8 October 2010; pp. 81-90.

64. Bumgardner, M.S.; Nicholls, D.L. Sustainable Practices in Furniture Design: A Literature Study on Customization, Biomimicry, Competitiveness, and Product Communication. Forests 2020, 11, 1277. [CrossRef]

65. Lihra, T.; Graf, R. Multi-channel communication and consumer choice in the household furniture buying process. Direct Mark. Int. J. 2007, 1, 146-160. [CrossRef]

66. Liang, Y.-P. The Relationship between Consumer Product Involvement, Product Knowledge and Impulsive Buying Behavior. Procedia Soc. Behav. Sci. 2012, 57, 325-330. [CrossRef] 